\title{
Psychological Peculiarities of Understanding by Students Internet Texts*
}

\section{Психологічні особливості розуміння студентами Інтернет-текстів **}

\author{
Serhii Maksymenko ${ }^{1}$ \\ DSc. in Psychology, Professor, \\ Active member of the National \\ Academy of Educational Sciences \\ of Ukraine
}

\author{
Сергій Максименко ${ }^{1}$ \\ доктор психологічних наук, \\ профессор, \\ дійсний член НАПН України
}

E-mail: 2883320@gmail.com https://orcid.org/0000-0002-3592-4196

Olena Nemesh ${ }^{2}$

DSc. in Psychology, Professor
Олена Немеш ${ }^{2}$

доктор психологічних наук, профессор

E-mail: ladyhelen2016@ukr.net https://orcid.org/0000-0001-8620-3279
Ksenia Maksymenko ${ }^{3}$
DSc. in Psychology, Professor

Ксенія Максименко ${ }^{3}$ доктор психологічних наук, профессор

\section{E-mail: ksenia.maximenko@gmail.com https://orcid.org/0000-0002-6102-2479}

\section{Alexander Nabochuk ${ }^{4}$ \\ $\mathrm{PhD}$. in Psychology}

\section{Олександр Набочук ${ }^{4}$} кандидат психологічних наук

E-mail: nab ol@ukr.net

https://orcid.org/0000-0002-1448-7687

\footnotetext{
* This research was funded by the Ministry of Education and Science of Ukraine, RN 0118 U003098

** Дослідження виконане за фінансової підтримки Міністерства освіти і науки України, реєстраційний номер RN $0118 \mathrm{U} 003098$
} 

${ }^{1}$ G.S. Kostyuk Institute of Psychology of NAES of Ukraine
2, Pankivska Str., Kyiv, Ukraine, 01033
${ }^{2}$ Rivne State University of the Humanities
12, Stepan Bandera Str., Rivne, Ukraine, 33000
${ }^{3}$ National Academy of the Internal Affairs of Ukraine
1, Solomenska Str., Kyiv, Ukraine, 03035
${ }^{4}$ Rivne Regional State Administration,
1, Education Square, Rivne, Ukraine, 33028
${ }^{1}$ Інститут психологіі імені Г.С. Костюка НАПН Украӥни $\triangle$ вул. Паньківська, 2, Київ, Україна, 01033
${ }^{2}$ Рівненський державний гуманітарний університет вул. Степана Бандери, 12, Рівне, Україна, 33000
${ }^{3}$ Начіональна Академія внутрішніх справ України вул. Соломенська, 1, Київ, Україна, 03035
${ }^{4}$ Рівненська обласна державна адміністрація $\bowtie$ Майдан Просвіти, 1, Рівне, Україна, 33028

Original manuscript received December 07, 2019

Revised manuscript accepted September 15, 2020

\begin{abstract}
The purpose of the article is to show psychological peculiarities of understanding by students Internet texts and to determine the predictors of such understanding.

Methods and methodical instrumentation of the research. The following scientific methods were used as the basis of the research: holistic analysis of the text, problem-thematic analysis, also comparative analysis. The following methods have also been used to study the research material: the descriptive method; the method of distributive analysis; the method of syntactic transformation. Also we used the author's questionnaire to determine the goals of interpersonal communication in the Internet space (Nabochuk, 2020); the questionnaire (Shkuratova, 2019), which has the aim to determine the motives of direct and indirect interpersonal communication; the questionnaire with the purpose to provide diagnostics of interpersonal relationships by T. Leary (The questionnaire of diagnostics of interpersonal relationships, 2018).

The results of the research. It was built a semantic space that characterized the process of understanding of artistic Internet texts of journalistic discourse. Students evaluated the content of these texts by 30 bipolar scales, which were combined after factor analysis into 7 blocks of factors that characterize the "evaluation" of a particular Internet text. (1). "The Assessment»: successful - unsuccessful; interesting uninteresting; strong - weak; pleasant - unpleasant; predicative - non-predicative. (2). "Tension or Strength»: difficult - easy to understand; tense - frivolous;
\end{abstract}


exceptional - everyday; chained - free; active - inactive; aggressive - non-aggressive; authoritarian - democratic. (3). "Realism or vitality»: natural - fictional; near far; real - unreal. (4). "Emotional tone»: pessimistic - optimistic; sad - cheerful; selfish - unselfish; suspicious - acceptable. (5). "Depth or psychological content»: psychological - non-psychological; reflective - non reflective; serious - unserious; reasonable - unreasonable; logical - illogical; convenient - inconvenient; dialogical monologue; dependent - independent. (6). "The Abstractness»: abstract - concrete; fantastic - real. (7). "Multifaceted»: multifaceted - one-sided; complex - simple; compressed - expanded.

Conclusions. According to the results of our research, we determined four main psychological peculiarities of understanding by students Internet texts. These peculiarities are: (1) understanding the Internet text by its contextuality, the predictors of which are: reality, versatility, paradigm, descriptiveness, deepness, subjectiveness and personally centered qualities; (2) understanding the Internet text by its psychological context, which includes such predictors, as: psychological justification, compressiveness, interest, entertaining, satisfaction, harmoniousness, emotiveness, expressiveness; (3) understanding the Internet text by its emotional context and predictors, such as: comfort, stylistic expressiveness, convenience, expressiveness, lightness, colloquial features, journalistic style of writing; (4) understanding the Internet text by its multifaceted paradigm, which is characterized by such predictors: paradigmatic, space, being updated, its stimulating, dialogic content, comfort characteristics of perceiving, frivolousness.

Key words: Internet text, understanding, psychological peculiarities of understanding, predictors of understanding, contextuality, psychological context, emotional context, multifaceted paradigm.

\section{Introduction}

Transformational processes in contemporary society affect a variety of areas of human life, including the field of virtual communication. In accordance with these processes, the constant use of Internet technologies has become an integral part of the activities and communication of the individual in many dimensions of self-realization of the person: from the field of professional-functional to intimate-personal one (Barnes, 2009; Lawson \& Leck, 2006; Nowak, Watt \& Walther, 2009). Therefore, among the current issues of contemporary psychology stands out an extremely important research area - the study of psychological features of the use of Internet technologies (Boyd, 2007; Rains \& Scott, 2007; Walther, 2011). 
This problem acquires important scientific status and research significance also because the World Wide Web takes over all the functional parameters of the huge competency of human knowledge, the mastery of which attracts everyone, sometimes even leading to Internet addiction (Derks, Bos \& Grumbkow, 2007; Ishkhanyan, Boye \& Mogensen, 2019). The immersion into open information immensities can lead to the suppression of the existential potential of the person, change his/her behavior, increase his/her addictiveness and manipulation (Gonzales \& Hancock, 2008; Kim \& Dindia, 2011).

It should be noted that contemporary Internet and communicative system are relatively new areas of human activity that are developing rapidly (Key-DeLyria, Bodner \& Altmann, 2019). There are not a lot of researches of the person's current online behavior, although this topic attracts the attention of researchers from many scientific and interdisciplinary fields. Accordingly, it is important to study the psychological nature of Internet communication as computermediated processes (Heino, Ellison \& Gibbs, 2010). After all, the multidimensionality of virtual communication has led to the fact that the Internet has created new configurations of classical measurements of the communicative process (Antheunis, Valkenburg \& Peter, 2010; Hall, Park, Song \& Cody, 2010).

In such a way as the Internet has becoming understood as a mean of mass communication, it became clear that neither mass nor the either category of communication itself could be defined for all situations and contexts, but instead had to be constantly rethought in relation to the specificity of each situation of everyday life (Baym, 2010). Also Internet communication has to take into account personal and situational variables (Pimperton \& Nation, 2010). It should be noted that the Internet changes the characteristics of the traditional model of mass communication, that is the paradigm «Source - Message - Recipient», has been forming a completely new combination of known laws in Psychology and the effects of information exchangings (Agrawal, 2020; Ramirez \& Wang, 2008). This is the most evident for younger generation of the whole Internet communication (Stephens \& Rains, 2011).

The results of the theoretical and empirical analysis of the peculiarities of virtual communication point to the tendency towards the gradual displacement of virtual communication, due to the proliferation of new information technologies (Astle \& Scerif, 2011). Empirical 
results emphasized on the aggravation of interpersonal and intrapersonal conflicts, which are the result of socio-political changes taking place in a modern society and reducing them (Rezaei \& Mousanezhad Jeddi, 2020). The persistence of the person to the action of addictive people is determined by one who in a virtual reality appears on the background of socio-economic changes, when many people have the desire to escape from the problems.

Virtual communication is the most actively implemented in the context of the usage of social networks which allow not only to exchange information, but also to establish new contacts, receive emotional feedback, and meet the frustrated needs in a communicative sphere (Amichai-Hamburger, 2005).

For people who are dependent on social networks the communicative process acquires some specific changes: an absolute advantage is given to virtual communication, with the gradual loss of the ability to be included into the immediate «live» interaction; communicative activity in the network becomes compulsive in nature; when installing contacts in a network a virtual image is used predominantly, which is significantly different from a real «Me»; there is a tendency towards the implementation of socially disapproving trends, verbal aggression, boiling and so on (Wright \& Webb, 2011).

Analyzing gender differences in virtual communication, girls were found to be guided by virtual interpersonal relationships to maintain close interpersonal relationships in the network, while boys were more attracted to the possibility of a cyber sex with different partners. Girls' communication is also characterized by greater emotionality and focus on the process of building relationships, while boys are more concentrated on both activity and its results. For girls, communicating in social networks and getting signs of attention from the opposite sex is so called means to increase self-esteem and self-confidence. Instead of them the boys interact each other more often in the social network on behalf of the «ideal self», which prevents the consolidation of the positive emotional influence received on the network in the context of real functioning of the person (Lawson \& Leck, 2006).

Thus, the study of psychological features of the use of Internet technologies by different groups of users is relevant in both theoretical and practical sense. In such a way the problem of contemporary psychological researches has the aim to actualize cognitions and to 
provide optimization of the interaction of the person with the Internet. According to this, the main purpose of our research is to show the results of our own empirical study which has to determine the psychological characteristics of interpersonal communication of students in the Internet space.

So, the purpose of the article is to show psychological peculiarities of understanding by students Internet texts and to determine the predictors of such understanding.

\section{Methods and Methodical Instrumentation of the Research}

The following scientific methods were used as the basis of the research: holistic analysis of the text, problem-thematic analysis, also comparative analysis. The following methods have also been used to study the research material: the descriptive method; the method of distributive analysis; the method of syntactic transformation.

The empirical methods of our research are: (1) the author's questionnaire to determine the goals of interpersonal communication in the Internet space (Nabochuk, 2020); (2) the questionnaire (Shkuratova, 2019), which has the aim to determine the motives of direct and indirect interpersonal communication; (3) the questionnaire with the purpose to provide diagnostics of interpersonal relationships by T. Leary (Metodyka diahnostyky..., 2018).

The methods of math analysis and statistical data processing there were: content analysis, T-criterion of Wilcoxon, U-criterion of MannWhitney, factor analysis, semantic differential method.

\section{Participants}

The characteristics of the sample in our research: the students of Rivne State University of the Humanities and of Lesia Ukrainka Eastern European National University were participated. These students were of age 17-24, they regularly and actively have used the Internet to communicate ( $n=376$ people, including 152 students of the faculties of humanities (34 boys and 118 girls). 129 students have studied at of technical specialties ( 80 boys and 49 girls), 31 of them were participants of the students' Internet forum (14 boys and 19 girls), 64 participants have formed a group which has participated in a specially organized 
extracurricular communicative process in the form of discussion of various topics (30 boys and 34 girls). All respondents were differentiated into subgroups: (1) by communication directly and indirectly measured by the Internet; (2) by gender differential (boys and girls); (3) by specialties (humanitarian and technical ones).

\section{The Results of the Research and Their Discussion}

The research of the goals of interpersonal communication of students in the Internet space, which was carried out by a specially designed questionnaire (Nabochuk, 2020), showed that all seven research goals (to make contacts, to provide understanding, information, the emotional goal, the purposes of coordination, motivation, relationships), which are characterized of both direct and indirect process of Internet communication. However, they have different levels of manifestation (see Table 1).

Table 1. The objectives of direct and Internet mediated interpersonal communication of students

\begin{tabular}{lll}
\hline \multicolumn{1}{c}{ Goals of communication } \\
\hline $\begin{array}{l}\text { The level } \\
\text { of manifestation }\end{array}$ & $\begin{array}{l}\text { Immediate } \\
\text { communication }\end{array}$ & $\begin{array}{l}\text { Mediation in } \\
\text { Internet communication }\end{array}$ \\
\hline High & (a) contact & (a) informational \\
Average & (b) understanding & (a) contact \\
Low & (a) informational & (b) understanding \\
& (b) emotional coordination & (a) emotional contact \\
& (a) motivating & (b) coordination \\
& (b) installation of the relationships & (c) relationships establishing \\
& & (d) motivating
\end{tabular}

Qualitative interpretation of the obtained data shows that students underlined the main goals of direct communication as the aims of establishing contacts $(\mathrm{T}=10.744, \mathrm{p} \leq 0.01)$ and provide the whole understanding $(T=-7.324, p \leq 0.01)$, and the goal which was seen as the one which has been in a great degree Internet-mediated, such as informational purpose $(T=-6.960, p \leq 0.01)$. In both direct and Internet-mediated communication, students are reluctant to stimulate the partner's activity to perform certain actions (to motivate), as well 
as to fix their place in the system of role and status connections (to establish relationships). In such a way we have to note that the goals of communication which are Internet-mediated, to a lesser extent than direct, are the means of arising the emotional experience of the partner (emotional goal: $\mathrm{T}=-9.750, \mathrm{p} \leq 0.01$ ), mutual orientation, coherence of actions (coordination goal: $\mathrm{T}=-7.397, \mathrm{p} \leq 0.01$ ).

The results of the research of the motives of direct and Internetmediated technologies of interpersonal communication of students (we used the questionnaire (Shkuratova, 2019)) presented in Table 2.

Table 2. The motives of direct and Internet-mediated interpersonal communication of students

\begin{tabular}{|c|c|c|}
\hline \multicolumn{3}{|c|}{ Motives of communication } \\
\hline $\begin{array}{l}\text { The level of } \\
\text { manifestation }\end{array}$ & $\begin{array}{l}\text { Immediate } \\
\text { communication }\end{array}$ & $\begin{array}{l}\text { Mediation in } \\
\text { Internet communication }\end{array}$ \\
\hline High & $\begin{array}{l}\text { (a) emotional and moral } \\
\text { (b) exchanging of views } \\
\text { (c) entertainment }\end{array}$ & $\begin{array}{l}\text { (a) exchanging of views } \\
\text { (b) entertainment }\end{array}$ \\
\hline Average & $\begin{array}{l}\text { (a) conventional } \\
\text { (b) interest in people } \\
\text { (c) alterocentric } \\
\text { (d) egocentric } \\
\text { (e) vital }\end{array}$ & $\begin{array}{l}\text { (a) emotional and moral } \\
\text { (b) conventional } \\
\text { (c) alterocentric } \\
\text { (d) interest in people }\end{array}$ \\
\hline Low & $\begin{array}{l}\text { (a) business } \\
\text { (b) negative } \\
\text { (c) self-affirmation } \\
\text { (d) cognitive }\end{array}$ & $\begin{array}{l}\text { (a) egocentric } \\
\text { (b) vital } \\
\text { (c) business } \\
\text { (d) negative } \\
\text { (e) self-affirmation } \\
\text { (f) cognitive }\end{array}$ \\
\hline \multicolumn{3}{|c|}{ Intensity of communication motives } \\
\hline High & (a) entertainment & (a) entertainment \\
\hline Average & $\begin{array}{l}\text { (a) conventional } \\
\text { (b) emotional and moral } \\
\text { (c) interest in people } \\
\text { (d) alterocentric } \\
\text { (e) egocentric }\end{array}$ & $\begin{array}{l}\text { (a) exchanging of views } \\
\text { (b) interest in people } \\
\text { (c) emotional and moral } \\
\text { (d) conventional }\end{array}$ \\
\hline Low & $\begin{array}{l}\text { (a) negative } \\
\text { (b) business } \\
\text { (c) self-affirmation } \\
\text { (d) vital } \\
\text { (e) cognitive } \\
\text { (f) exchanging of views }\end{array}$ & $\begin{array}{l}\text { (a) vital } \\
\text { (b) business } \\
\text { (c) alterocentric } \\
\text { (d) egocentric } \\
\text { (e) negative } \\
\text { (f) self-affirmation } \\
\text { (g) cognitive }\end{array}$ \\
\hline
\end{tabular}


Qualitative interpretation of the obtained data having been done by us to state that the leading motives of direct and Internet-mediated interpersonal communication of students are the motives of exchanging the ideas and providing entertainment. It should be noted that the direct communication of students is also dominated by emotional and moral motives.

Statistically significant differences, which have underlined the direct process of interpersonal communication, were found by emotional and moral process of communication $(T=-7.612, \quad \mathrm{p} \leq 0.01)$, by alterocentric $(T=-3.510, p \leq 0.01)$, egocentric $(T=-6.789, p \leq 0.01)$, vital $(\mathrm{T}=-3.973, \mathrm{p} \leq 0.01)$, business $(\mathrm{T}=-3.640, \mathrm{p} \leq 0.01)$ motives, as well as the motive of interest of a person $(\mathrm{T}=-2.227, \mathrm{p} \leq 0.01)$.

We've to note that we did not find statistically significant differences in the process of Internet-mediated and interpersonal communication of students. It can help us to conclude that students more like Internet-mediated process of communication, they communicate in Internet space more than $70 \%$ of the process of communication in the whole, that's why there is no statistically significant differences in the results having been gained by us.

The analysis of the intensity of motives showed the priority of entertainment in direct and Internet-mediated communication. Identified by us significant differences allow us to conclude that the intensity of the motive of entertainment in direct communication is higher than in the Internet-mediated process $(T=-3.370, \mathrm{p} \leq 0.01)$. Thus, in the space of Internet students are much more like to share thoughts than in direct process of communication, prone to a simple exchange of ideas, which means situations where communication is organized mainly to compare students' views with the ideas of other people, as well as the interest to personal specific traits of other students and characteristics of a virtual partner of communication.

The interpretation of the Internet-mediated motives of our research has to identify that the boys if to compare them with girls had more emphasized business motive $(U=-2.418, p \leq 0.01)$ and the motive of showing entertainment $(U=-2.350, p \leq 0.01)$. Girls are dominated by emotional and moral motives $(U=-2.342, p \leq 0.05)$, they in a great degree show the interest to the other person $(U=-3.059, \mathrm{p} \leq 0.05)$; also we diagnosed the conventional motive $(U=-1.995, p \leq 0.01)$. The research of the peculiarities of the motives of Internet communication of 
students of humanities and technical specialties showed that students of technical specialties, compared with their peers, more often implemented a business motive $(U=-2.870, p \leq 0.01)$.

The analysis of the dynamics of the manifestation of the leading goals and motives of the Internet-mediated interpersonal communication of students in the process of age development and professional development is presented by Fig. 1. Thus, showed data allowed us to state that in the Internet communication of students the informational goal has a positive dynamics, which is expressed in the growth of its importance from the $1^{\text {st }}$ to the $5^{\text {th }}$ cources of syudents' studing at the university (at the $1^{\text {st }}$ year -3.5 ; at the $2^{\mathrm{d}}$ year -3.8 ; at the $3^{\mathrm{d}}$ year 4 ; at the $4^{\text {th }}$ course -4.3 ; at the $5^{\text {th }}$ course -4.3$)$. The motive of entertainment has a negative dynamics: the significance of this motive decreases from the $1^{\text {st }}$ to the $5^{\text {th }}$ cources of syudents' studing at the university (at the $1^{\text {st }}$ year -8.3 ; at the $2^{\mathrm{d}}$ year -7.1 ; at the $3^{\mathrm{d}}$ year 6.8 ; at the $4^{\text {th }}$ course -5.8 ; at the $5^{\text {th }}$ course -5.4 ). The dynamics of the motive of exchanging the ideas is also negative: the significance of this motive decreases from the $1^{\text {st }}$ to the $5^{\text {th }}$ cources of syudents' studing at the university (at the $1^{\text {st }}$ year - the result is 12.7; at the $2^{\text {d }}$ year -6.3 ; at the $3^{\text {d }}$ year -6.5 ; at the $4^{\text {th }}$ course -5.8 ; at the $5^{\text {th }}$ course -5.4 ).

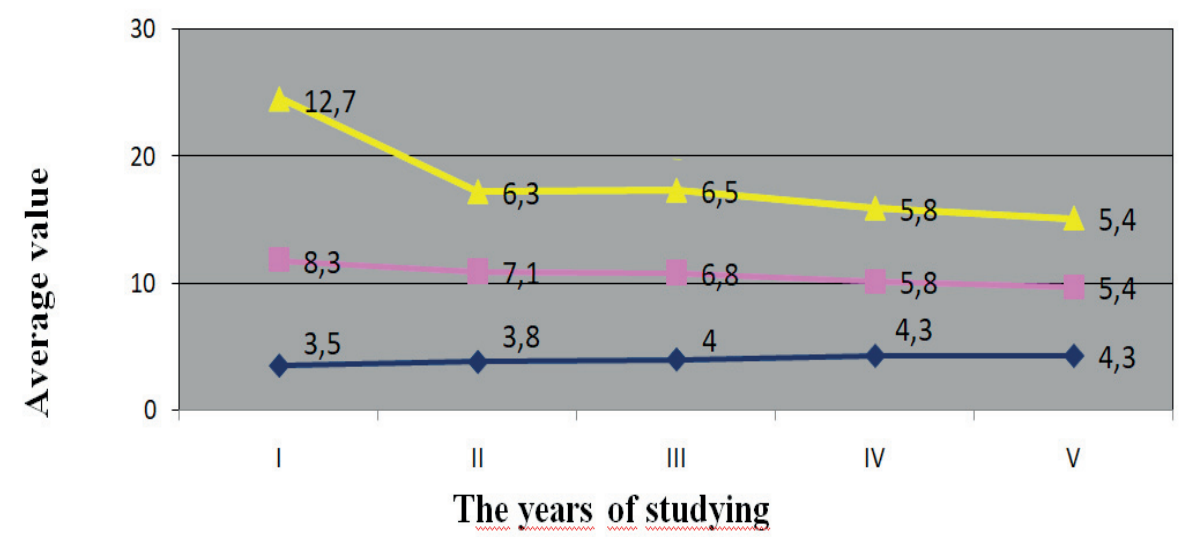

-A motive for exchanging views $\quad \rightarrow$-A motive of entertainment $\rightarrow$-Informational purpose

Fig. 1. The dynamics of the leading goals and motives of Internet-mediated communication of students 
The analyses of the specifics of the main purpose and motives of communication mediated by the Internet space has revealed the following results: (a) the dynamics of the information goal of boys is positive from the $1^{\text {st }}$ to the $3^{\mathrm{d}}$ cources and it is negative from the $3^{\mathrm{d}}$ to the $5^{\text {th }}$ cources; the dynamics of the results of girls is more positive from the $1^{\text {st }}$ to the $5^{\text {th }}$ cources; (b) the motive of having been entertained in Internet communication of boys and girls hasn't been characterized by dynamic characteristics; (c) the dynamics of the motive of exchange of thoughts of boys is positive from the $1^{\text {st }}$ to the $3^{\mathrm{d}}$ cources and it is negative from the $3^{\mathrm{d}}$ to the $5^{\text {th }}$ cources, but girls have more negative results from the $1^{\text {st }}$ to the $5^{\text {th }}$ cources. It should also be noted that students of humanities and technical specialties did not find any peculiarities of the dynamics of the leading goals and motives of communication mediated by the Internet space.

The comparative research of the content, functions and positions of direct and Internet-mediated communication of students had been conducted using the content analysis. The main categories of this analysis were those ones that constitute the process of communication (substantive, functional and positional categories); the units of the analysis - they were highlighted in the data of the constituent components (cognitive, emotional and motivational components, the component of the activity, the information, the regulatory components, the affective one, also as open, remote and closed components). The complex of interrelationships of the various components of communication did not allow the identification of so-called «pure», ideal units of the analysis, which had revealed a number of additional, «mixed» characteristics in the substantive and functional components of communication (Table 3).

Table 3. A content, functions and positions of direct and Internet-mediated interpersonal communication of students (in \%)

\begin{tabular}{lllll}
\hline $\begin{array}{l}\text { Components } \\
\text { of the } \\
\text { communication }\end{array}$ & $\begin{array}{l}\text { Components that } \\
\text { make up a process of } \\
\text { communication }\end{array}$ & $\begin{array}{l}\text { Direct } \\
\text { communication } \\
\text { act }\end{array}$ & $\begin{array}{l}\text { Internet } \\
\text { communication }\end{array}$ & $\begin{array}{l}\text { Statistically } \\
\text { significant } \\
\text { differences }\end{array}$ \\
\hline Meaningful & cognitive & $\mathbf{5 9}$ & $\mathbf{2 9}$ & $\begin{array}{l}\boldsymbol{\varphi}^{*}=\mathbf{4 . 1}, \\
\mathbf{p} \leq \mathbf{0 . 0 1}\end{array}$ \\
& $\begin{array}{l}\text { Cognitive-emotional } \\
\text { Cognitive-motivational }\end{array}$ & 16 & 11 & \\
& \begin{tabular}{l} 
cognitive-activity \\
\hline
\end{tabular} & 0 & 16 & \\
\hline
\end{tabular}


Психологічні особливості розуміння студентами...

\begin{tabular}{|c|c|c|c|c|}
\hline & emotional & 4 & 26 & $\begin{array}{l}\varphi^{*}=4.5 \\
p \leq 0.01\end{array}$ \\
\hline \multirow{5}{*}{ Functional } & motivational & 11 & 7 & \multirow{5}{*}{$\begin{array}{l}\varphi^{*}=2.04 \\
p \leq 0.05\end{array}$} \\
\hline & $\begin{array}{l}\text { cognitive-emotional- } \\
\text { motivational }\end{array}$ & 2 & 3 & \\
\hline & informative & 55 & 40 & \\
\hline & informative- regulatory & 17 & 15 & \\
\hline & $\begin{array}{l}\text { informative- regulatory- } \\
\text { affective }\end{array}$ & 7 & 12 & \\
\hline \multirow{5}{*}{ Positional } & regulatory & 9 & 3 & \multirow{5}{*}{$\begin{array}{l}\varphi *=1.64 \\
p \leq 0.05\end{array}$} \\
\hline & affective- regulatory & 2 & 2 & \\
\hline & open & 70 & 80 & \\
\hline & removed & 23 & 15 & \\
\hline & closed & 7 & 5 & \\
\hline
\end{tabular}

It was found that the content of direct interpersonal communication of students is dominated by the cognitive component (59\%), which exceeds the same figure in Internet-mediated communication (29\%). The semantics of Internet-mediated communication is marked by the predominance of the emotional component (26\%), which exceeds the same figure in the process of direct communication (4\%).

A comparative study of the function of direct and Internet-mediated interpersonal communication of students revealed the predominance of the informational component in the process of direct communication (55\% and $40 \%$ of respondents). In such a way we have to note that the positional component of interpersonal communication mediated by the Internet, in comparison with the direct one, is dominated by the open subcomponent (in the structure of positional component $80 \%$ and $70 \%$ of respondents).

The analysis of the results of our research of the main types of interpersonal relationships by three measures of severity (by using the questionnaire by T. Leary (Metodyka diahnostyky..., 2018)) is presented by Fig. 2.

The results of the research show that the average indicators of different types of relationships in a case of direct and Internetmediated communication of students are in the range of minimum and average values, and in the Internet environment with all types of interpersonal relationships, which are more less pronounced than in the process of direct communication. This indicates the psychological 
health and adequacy of most the subjects, as well as indicates the features of the Internet environment, which allows the students to build more constructive relationships in the process of communication. The obtained differences were confirmed statistically using the T-criterion of Wilcoxon.

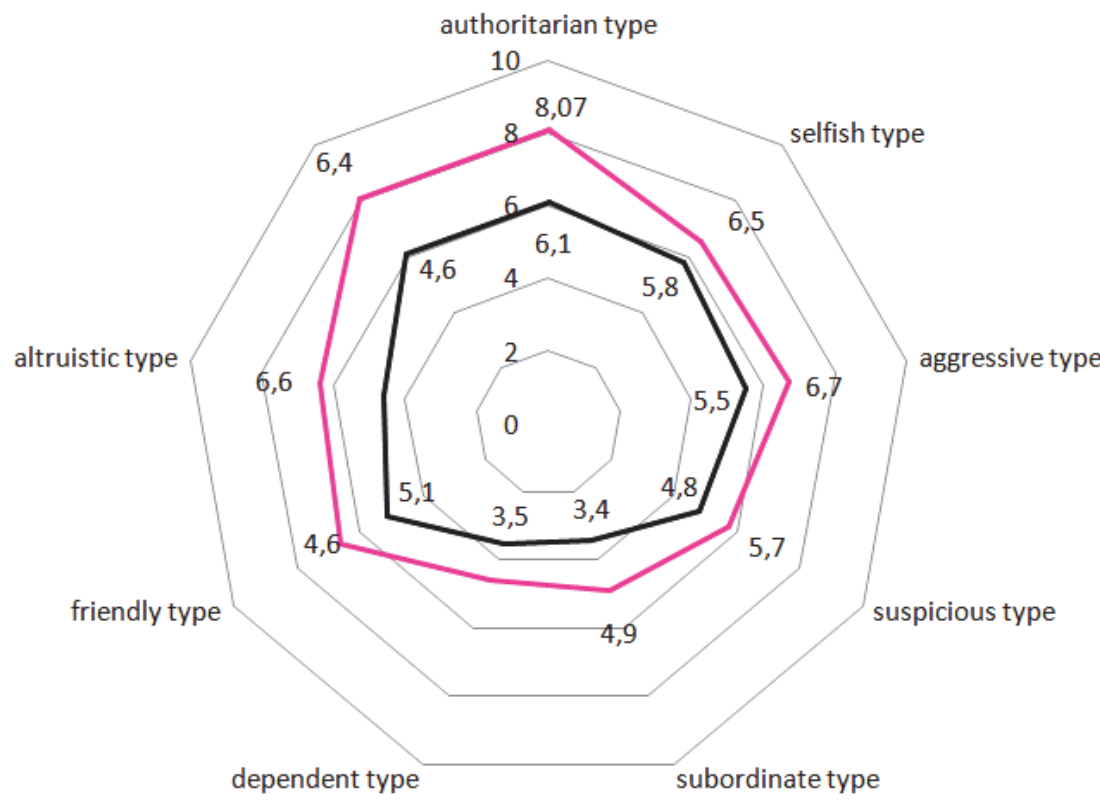

- Direct communication $\quad$ Internet-mediated communication

Fig. 2. The average value of types of interpersonal relationships in direct and Internet-mediated communication of students

Boys in comparison with girls in Internet communication are dominated by selfish ( $\mathrm{U}=0.045, \mathrm{p} \leq 0.05)$ and aggressive $(\mathrm{U}=0.041$, $\mathrm{p} \leq 0.05)$ types of interpersonal relationships, and girls are dominated by suspicion ( $U=0.046, p \leq 0.05)$ and friendliness $(U=0.049, p \leq 0.05)$. The obtained differences were confirmed by us statistically using the U-criterion Mann-Whitney. Also, the types of interpersonal relationships in the process of communication mediated by the Internet in a great degree differed, when we tell about students of humanities and technical specialties in terms of authoritarianism and selfishness, which are the 
based characteristics of students of technical specialties (authoritarianism: $\mathrm{U}=0.048, \mathrm{p} \leq 0.05$; selfishness: $\mathrm{U}=0.043, \mathrm{p} \leq 0.05$ ).

The analysis of the peculiarities between the features of communication (goals, motives and types of interpersonal relationships), mediated by the space of Internet, and the psychological adaptation of students, was carried out on the basis of factor analysis. It was found that the ability to obtain the information in the process of Internet communication, to establish a contact with the partner of communication, as well as to build productive relationships are interrelated with selfacceptance, emotional comfort and adaptability of students.

It is also established that students of humanities provide in the best way:

(a) the implementation of a wide range of goals of communication in the Internet environment, the manifestation of the variety of different types of interpersonal relationships which are interrelated with self-acceptance and internal control;

(b) the manifestation of suspicious and subordinate types of interpersonal relationships in Internet-mediated communication which is interrelated with maladaptation.

Students of technical specialties are characterized by:

(a) the ability to obtain information, to encourage partners to communicate, to express emotions and to understand the partner of communication by the Internet; this ability is interrelated with adaptability;

(b) entertainment, formal contacts, manifestation of selfish types of interpersonal relationships in the process of Internet-mediated communication, which are interrelated with maladaptation.

The above data according to the connections of Internet communication, indicators, including depending on the profile of students' training, can be considered as quite new, as in this perspective other researchers have not yet provided their scientific researches.

During the experimental studying students were offered Internet texts (COVID-19: Antykryzovyi zakon..., 2020; Osnovni ekolohichni problemy Ukrainy, 2014; Systema osvity v Ukraini, 2015; Zdorovyi sposib zhyttia..., 2016). The main method of recording the results of comprehension of the content of these texts was the semantic differential (SD), and in addition to using the standard 25-scale version of the analysis of text comprehension (proposed by O.P. Zhuravlyov) and 
9-scale personal differential (proposed by O.G. Shmelyov) we developed special its variants. These are: a 30 -scale bipolar variant of SD, the scales of which orient the person to the evaluation of various parameters of the Internet text, and 24-scale unipolar variant of SD with the same content of scales (Serkin, 2016). In addition to SD, for this purpose the color test of relations (proposed by A. Etkind) (Kolorystychnyi test..., 2015) was used. Also we used the value spectrum (CA) developed by D. Leontiev on the basis of A. Maslov's list of values (Leontiev, 2018).

In our research we built a semantic space that characterizes the process of understanding of artistic Internet texts of journalistic discourse: (a) «COVID-19: Antykryzovyi zakon opryliudneno» (2020); (b) «Zdorovyi sposib zhyttia: osnovy ta pryntsypy» (2016); (c) «Osnovni ekolohichni problemy Ukrainy» (2014); (d) «Systema osvity v Ukraini» (2015). Students evaluated the content of these texts by 30 bipolar scales, which were combined after factor analysis into 7 blocks of factors that characterize the «evaluation» of a particular Internet text:

(1) «The Assessment»: successful - unsuccessful; interesting uninteresting; strong - weak; pleasant - unpleasant; predicative non-predicative.

(2) «Tension or Strength»: difficult - easy to understand; tense frivolous; exceptional - everyday; chained - free; active - inactive; aggressive - non-aggressive; authoritarian - democratic.

(3) «Realism or vitality»: natural - fictional; near - far; real - unreal.

(4) «Emotional tone»: pessimistic - optimistic; sad - cheerful; selfish - unselfish; suspicious - acceptable.

(5) «Depth or psychological content»: psychological - nonpsychological; reflective - non reflective; serious - unserious; reasonable - unreasonable; logical - illogical; convenient inconvenient; dialogical - monologue; dependent - independent.

(6) «The Abstractness»: abstract - concrete; fantastic - real.

(7) «Multifaceted»: multifaceted - one-sided; complex - simple; compressed - expanded.

As a result of grouping proposed by us scales by selected factors and average scores on scales that were the part of one factor, a table of connotative evaluations of texts based on all selected factors for each subject was constructed. In such a way connotative assessments was reflected the attitude of studied by students Internet texts. 
Students were participated in a research organized by using a modified version of «Metodika lichnostnyh konstruktov Dzhona Kejli» by J. Kelly (Serkin, 2016). The dominant content of objects of Internet texts were grouped into 12 triplets, and recipients were required to make a triadic choice and to indicate the characteristics by which two texts from each triad are opposed to the third one, in such a way - to formulate personal constructs. Here is the example of a fragment of the protocol of one of the students:

(a) «COVID-19: Antykryzovyi zakon opryliudneno» [COVID-19: Anti-crisis law was published]», «Zdorovyi sposib zhyttia: osnovy ta pryntsypy» ["Healthy lifestyle: Fundamentals and Principles»] - health is the highest value in our life;

(b) «Osnovni ekolohichni problemy Ukrainy» [«The main environmental problems of Ukraine»], «Systema osvity v Ukraini» ["The System of Education in Ukraine»] - contemporary problems of Ukrainian society;

(c) «COVID-19: Antykryzovyi zakon» [COVID-19: Anti-crisis law was published]» - the organization of the educational system in Ukraine in the conditions of a pandemic;

(d) «Zdorovyi sposib zhyttia: osnovy ta pryntsypy» ["Healthy lifestyle: Fundamentals and Principles»], "Osnovni ekolohichni problemy Ukrainy» ["The main environmental problems of Ukraine»] a dialogue between the Self and the Environment - the aim of the formation of a single eco-organism;

(e) «COVID-19: Antykryzovyi zakon» [COVID-19: Anti-crisis law was published]», «Osnovni ekolohichni problemy Ukrainy» ["The main environmental problems of Ukraine»] - problems of the world ecosystem in the conditions of a pandemic;

(f) «Zdorovyi sposib zhyttia: osnovy ta pryntsypy» [«Healthy lifestyle: Fundamentals and Principles»], «Systema osvity v Ukraini» ["The System of Education in Ukraine»] - psychological determinants of a healthy lifestyle, having been laid down in the paradigm of educational system of Ukraine.

The number of non-synonymous personal constructs having been used by each student was estimated for each researcher according to the material of his/her protocol. This number as the indicator of a cognitive complexity of semantic constructs of Internet texts was studied by each student in accordance with the differentiation which was correlated with 
his/her assessments of texts for each of the seven selected factors. It turned out that a cognitive complexity of each student in the process of understanding by him/her the Internet text correlates with such parameters of the text, as its «contextuality», "psychological context», «emotional context» and «multifaceted paradigm». Thus, there is a direct link between a cognitive and emotional evaluation of Internet text's comprehension. The depth of the understanding of each text determines student's attitude to it, and a positive attitude supports the emotional fixation on the Internet text: the desire to comprehend and to understand it.

The main result of the research by SD method is related by using the factor analysis. The dominant factors of the Internet text are: «Contextuality» $(\mathrm{C})$, «Psychological context» (PC), «Emotional context» (EC) and «Multifaceted paradigm» (MP). These parameters were defined as a universal semantic field in which the whole space of the student's subjective attitude to the elements of Internet texts is located, ordered and described.

The respondents were asked to rate each Internet text by 54 unipolar ten-point scales $(5,4,3,2,1,0,-1,-2,-3,-4,-5)$. The total group data matrices, obtained by us, were subjected by the procedure of factor analysis. As a result of data processing after rotation of factor structures according to the Varimax principle, four relatively independent, orthogonal factors were identified, the interpretation of them was given below.

The first factor «Contextuality» (37.4\% of a total variance) contains the inclusion of following scales, which are listed in descending order by the weight of each factor (Table 4). Factor load reflects the correlation of the vector (corresponding to one or another scale) of the selected factor and shows how it was expressed in the content of this scale and according to the content that this factor describes.

Table 4. The content of the first factor «Contextuality»

\begin{tabular}{lll}
\hline No & The name of the factor & The weight of each factor \\
\hline 1. & realistic & 0.95 \\
2. & multifaceted & 0.93 \\
3. & paradigmatic & 0.91 \\
4. & descriptive & 0.90 \\
5. & deep & 0.87 \\
\hline
\end{tabular}


Психологічні особливості розуміння студентами...

\begin{tabular}{lll}
\hline 6. & subjective & 0.85 \\
7. & personally centered & 0.84 \\
8. & interesting & 0.81 \\
9. & specific & 0.78 \\
10. & vital & 0.76 \\
11. & frivolous & 0.74 \\
12. & superficial & 0.72 \\
\hline
\end{tabular}

The second selected factor «Psychological context» $(27.1 \%$ of a total variance) includes some characteristics; they were shown in Table 5.

Table 5. The content of the factor «Psychological context»

\begin{tabular}{lll}
\hline No & The name of the factor & The weight of the factor \\
\hline 1. & psychologically justified & 0.91 \\
2. & compressed & 0.89 \\
3. & interesting & 0.88 \\
4. & entertaining & 0.86 \\
5. & pleasant & 0.84 \\
6. & harmonious & 0.82 \\
7. & emotional & 0.80 \\
8. & expressive & 0.79 \\
9. & unilateral & 0.78 \\
10. & meaningful & 0.77 \\
11. & mystical & 0.76 \\
12. & abstract & 0.75 \\
13. & imaginary & 0.74 \\
14. & serious & 0.70 \\
15. & comfortable & 0.68 \\
\hline
\end{tabular}

The factor «Contextuality» and the factor «Psychological context» reflect Osgood's basic factor «The Depth». The third factor «Emotional context» $(24.2 \%)$ is represented by scales, which were shown in Table 6 .

Table 6. The content of the factor «Emotional context»

\begin{tabular}{lll}
\hline No & The name of the factor & The weight of the factor \\
\hline 1. & comfortable & 0.89 \\
2. & stylistically colored & 0.87 \\
3. & convenient & 0.86 \\
4. & expressive & 0.84 \\
5. & light & 0.82 \\
\hline
\end{tabular}


Psychological Peculiarities of Understanding by Students...

\begin{tabular}{lll}
\hline 6. & colloquial & 0.80 \\
7. & journalistic & 0.78 \\
8. & simple & 0.76 \\
9. & dialogic & 0.74 \\
10. & prudent & 0.72 \\
11. & cheerful & 0.70 \\
12. & optimistic & 0.69 \\
13. & non-predicative & 0.66 \\
14 & household & 0.64 \\
\hline
\end{tabular}

The fourth factor $(11.3 \%)$ we call «Multifaceted paradigm». It is represented by different scales (Table 7).

Table 7. The content of the factor «Multifaceted paradigm»

\begin{tabular}{lll}
\hline No & The name of the factor & The weight of the factor \\
\hline 1. & paradigmatic & 0.86 \\
2. & space & 0.84 \\
3. & updated & 0.82 \\
4. & stimulating & 0.77 \\
5. & dialogic & 0.75 \\
6. & comfortable & 0.73 \\
7. & frivolous & 0.72 \\
8. & cheerful & 0.71 \\
9. & emotional & 0.70 \\
10. & simple & 0.66 \\
11. & deployed & 0.64 \\
12. & specific & 0.61 \\
13. & logical & 0.60 \\
14. & dialogical & 0.58 \\
\hline
\end{tabular}

According to the semantic differential, we found that boys-students:

(a) tried to reach the realization of the motive of entertainment, contact, a motivational aspect of the activity, the informational goals, to provide aggressive, selfish and suspicious types of interpersonal relationships in the process of Internet communication which are interrelated with the acceptance of themselves and other people;

(b) the realization of the motive of exchanging of opinions and authoritarian types of interpersonal relations in the process of Internet-mediated communication is interconnected with emotional comfort of the person. 
For female students it is characterized:

(a) establishing contacts with the partner of communication, the ability to receive information, the possibility of understanding, exchanging views, the manifestation of aggressive, friendly and altruistic types of interpersonal relationships in the process of Internet-mediated communication; and these types are interrelated with self-acceptance;

(b) the inability to establish contacts, to exchange views in conjunction with the authoritarian and dependent type of interpersonal relationships in the process of Internet-mediated interpersonal communication; these types are interrelated with emotional discomfort;

(c) establishing relationships and a great entertainment in the process of Internet-mediated communication; it is interrelated with the acceptance of others and emotional comfort in general.

In this way, the Internet offers for its users, in such a way, in our case - for students, such great opportunities for social and professional possibilities with those people whom they know rather well in a real life, and with those people they meet online. These online social connections in a great degree can improve professional contacts and provide access to professional, economic, political and other kinds of information. The formation of social groups in the Internet is not limited and is does not suit for limited to career conditions, needs and interests. In contemporary social networks, there are many groups for those people who want to find other people with common interests and needs in the broadest areas of human life.

\section{Conclusions}

The results having been obtained in our research psychological characteristics of interpersonal communication of students in the Internet space showed that according to the main goals of direct communication students can see the establishment of social contacts and general socialized understanding. The Internet-mediated communication has so called informational purpose. In both types of communication, students are not inclined to the process of stimulating the activity of the partner to perform certain actions (to motivate), as well as to fix their place 
in the system of role and status relationships. It has been established that opportunities to obtain any information in the process of Internet communication, to establish contact with the partner of communication, as well as to build relationships with other people which are interconnected with self-acceptance, emotional comfort and adaptability.

The leading motives of students' communication are the motives of exchanging the ideas and gaining entertainment. Statistically significant differences in the process of direct interpersonal communication are found in the emotional-moral, alterocentric, egocentric, life, business, as well as the motives of having been interested in a man's person. The priority of the entertainment for both types of communication is set. However, the intensity of this motive in the process of direct communication is more higher than in Internet-mediated one. In the time context, the informational purpose of Internet communication of students has a positive dynamics - there is a great increase in its importance from junior to senior age. Negative dynamics is inherent for the motives of entertainment and exchanging of ideas.

According to the established gender differences, boys have more emphasized business motive, motive of being entertained than girls do; girls are characterized by dominated motives of emotional and moral sphere of the person, interest for the man's person and conventional motive. Boys are characterized by dominated selfish and aggressive types of interpersonal relationships, and girls have dominated suspiciousness and friendliness. Boys have positive dynamics of the informational goal from the first to the third year of studying at the university, and then it becomes more negative; as for girls, it is positive from the first to the senior courses. The dynamics of the motive for exchanging different ideas is just as positive for boys from the $1^{\text {st }}$ to the $3^{\mathrm{d}}$ years of studying, but from the $3^{\mathrm{d}}$ to the $6^{\text {th }}$ courses it is still negative. The girls are characterized by its negative dynamics from the first to the senior courses.

As for the results of male students the realization of the motive of entertainment, contact, motivational, informational goals, providing aggressive, selfish and suspicious types of interpersonal relationships in Internet communication are interrelated with the acceptance of themselves and others; and the realization of the motive of exchange of thoughts and authoritarian type of interpersonal relations is interconnected in a great degree with emotional comfort. As for female 
students, establishing contacts with the partner of communication, the ability to receive information, to understand it, to exchange the views, the manifestation of aggressive, friendly and altruistic types of interpersonal relationships in the process of Internet-mediated communication are interrelated with self-acceptance. Also as for female students the inability to establish contacts, to exchange ideas in conjunction with authoritarian and dependent types of interpersonal relationships are interrelated with emotional discomfort.

Students of technical specialties, compared with those ones, who are studying at the humanities, more often realize the business motive. These students have more emphasized parameters of authoritarianism and selfishness of their interpersonal relationships in the process of Internet communication. For the students of the humanities, the realization of a wide range of goals of communication in the Internet environment, the manifestation of a variety of types of interpersonal relationships are interrelated with self-acceptance and internal control; and the manifestation of suspicious and subordinate types of interpersonal relationships are interrelated with maladaptation. Students of technical specialties have the ability to obtain information, to encourage partners to communicate, to express emotions and to understand the partner of communication on the Internet. These qualities are interrelated with adaptability, entertainment, formal establishment of contacts, manifestation of selfish type of interpersonal relations in the process of Internet-mediated communication and also with maladaptation.

According to the results of our research, we determined four main psychological peculiarities of understanding by students the Internet texts. These peculiarities are:

(1) Understanding the Internet text by its contextuality, the predictors of which are: reality, versatility, paradigm, descriptiveness, deepness, subjectiveness and personally centered qualities.

(2) Understanding the Internet text by its psychological context, which includes such predictors, as: psychological justification, compressiveness, interest, entertaining, satisfaction, harmoniousness, emotiveness, expressiveness.

(3) Understanding the Internet text by its emotional context and predictors, such as: comfort, stylistic expressiveness, convenience, expressiveness, lightness, colloquial features, journalistic style of writing. 
(4) Understanding the Internet text by its multifaceted paradigm, which is characterized by such predictors: paradigmatic, space, being updated, its stimulating, dialogic content, comfort characteristics of perceiving, frivolousness.

The perspective of further researches is to increase in a great degree the opportunities for professional and personal development of students through Internet-mediated communication.

\section{References}

Agrawal, P.K. (2020). Psychological Model of Phonosemantics. Journal of Psycholinguistic Research, 49, 453-474. https://doi.org/10.1007/s10936-02009701-y

Amichai-Hamburger, Y. (2005). The social net: Understanding human behavior in cyberspace. Oxford, UK: Oxford University Press.

Antheunis, M.L., Valkenburg, P.M., \& Peter, J. (2010). Getting acquainted through social network sites: Testing a model of online uncertainty reduction and social attraction. Computers in Human Behavior, 26, 100-109. https://doi.org/10.1016/j. chb.2009.07.005

Astle, D., \& Scerif, G. (2011). Interactions between attention and visual shortterm memory (VSTM): What can be learnt from individual and developmental differences? Neuropsychologia, 49, 1435-1445. https://doi.org/10.1016/j. neuropsychologia.2010.12.001

Barnes, S.B. (2009). Relationship networking: Society and education. Journal of Computer-Mediated Communication, 14(3), 735-742. https://doi.org/10.1111/ j.1083-6101.2009.01464.x

Baym, N.K. (2010). Personal connections in the digital age. Cambridge, UK: Polity Press.

Boyd, D. (2007). Why youth V social network sites: The role of networked publics in teenage social life. In D. Buckingham (Ed.), Youth, Identity, and Digital Media (pp. 119-142). Cambridge: MIT Press.

COVID-19: Antykryzovyi zakon opryliudneno [COVID-19: Anti-crisis Law was Published] (2020). Voice of Ukraine, April 2. URL https://zib.com.ua/ua/142106covid-19_antikrizoviy_zakon_oprilyudneno_oficiyniy_tekst.html [in Ukrainian].

Derks, D., Bos, A.E., \& Grumbkow, J. (2007). Emoticons and social interaction on the Internet: The importance of social context. Computers in Human Behavior, 23, 842-849. https://doi.org/10.1016/j.chb.2004.11.013

Gonzales, A.L., \& Hancock J.T. (2008). Identity shift in computer-mediated environments. Media Psychology, 11, 167-185. https://doi.org/10.1080/15213260802023433

Hall, J.A., Park, N., Song, H., \& Cody, M.J. (2010). Strategic misrepresentation in online dating: The effects of gender, self-monitoring, and personality traits. Journal of Social and Personal Relations, 27(1), 117-135. https://doi. org/10.1177/0265407509349633

Heino, R.D., Ellison, N.B., \& Gibbs, J.L. (2010). Relationshopping: Investigating the market metaphor in online dating. Journal of Social and Personal Relationships, 27(4), 427-447. https://doi.org/10.1177/0265407510361614 
Ishkhanyan, B., Boye, K., \& Mogensen, J. (2019). The Meeting Point: Where Language Production and Working Memory Share Resources. Journal of Psycholinguistic Research, 48, 61-79. https://doi.org/10.1007/s10936-018-9589-0

Key-DeLyria, S.E., Bodner, T., \& Altmann, L.J.P. (2019). Rapid Serial Visual Presentation Interacts with Ambiguity During Sentence Comprehension. Journal of Psycholinguistic Research, 48, 665-682. https://doi.org/10.1007/s10936-01809624-9

Kim, J., \& Dindia, K. (2011). Online self-disclosure: A review of research. In K.B. Wright \& L.M. Webb (Eds.), Computer-mediated Communication in Personal Relationships (pp. 156-180). New York: Peter Lang.

Kolorystychnyi test vidnoshen A. Etkinda (2015). [The Color Test of Relations (Proposed by A. Etkind)]. URL https://dytpsyholog.com/2015/03/31/колірнийтест-відносин [in Ukrainian].

Lawson, H.M., \& Leck, K. (2006). Dynamics of Internet dating. Social Science Computer Review, 24(2), 189-208. https://doi.org/10.1177/0894439305283402

Leontiev, D. (2018). Test Smyslozhiznennye orientacii [Life-Sense Orientation Test]. URL https://medbib.in.ua/test-smyislojiznennyie-orientatsii-39994.html [in Russian].

Metodyka diahnostyky mizhosobystisnykh stosunkiv T. Liri [The Questionnaire of Diagnostics of Interpersonal Relationships] (2018). URL https://www.psuhologia. in.ua/images/dustan/ispl1.pdf [in Ukrainian].

Nabochuk, O. (2020). Opytuvalnyk vyznachennia tsilei mizhosobystisnoho spilkuvannia $v$ Internet-prostori [The Questionnaire to Determine the Goals of Interpersonal Communication in the Internet Space]. Rivne: Rivne State University of the Humanities [in Ukrainian].

Nowak, K., Watt, J.H., \& Walther, J.B. (2009). Computer mediated teamwork and the efficiency framework: Exploring the influence of synchrony and cues on media satisfaction and outcome success. Computers in Human Behavior, 25(5), 11081119. https://doi.org/10.1016/j.chb.2009.05.006

Osnovni ekolohichni problemy Ukrainy [The main environmental problems of Ukraine]. (2014). URL https://ecotown.com.ua/news/Osnovni-ekolohichni-problemyUkrayiny-u-2014-rotsi.

Pimperton, H., \& Nation, K. (2010). Suppressing irrelevant information from working memory: Evidence for domain-specific deficits in poor comprehenders. Journal of Memory and Language, 62(4), 380-391. https://doi.org/10.1016/j.jml.2010.02.005

Rains, S.A., \& Scott, C.R. (2007). To identify or not to identify: A theoretical model of receiver responses to anonymous communication. Communication Theory, 17(1), 61-91. https://doi.org/10.1111/j.1468-2885.2007.00288.x

Ramirez, A.Jr., \& Wang, Z. (2008). When online meets offline: An expectancy violation theory perspective on modality switching. Journal of Communication, 58(1), 20-39. https://doi.org/10.1111/j.1460-2466.2007.00372.x

Rezaei, A., \& Mousanezhad Jeddi, E. (2020). The Contributions of Attentional Control Components, Phonological Awareness, and Working Memory to Reading Ability. Journal of Psycholinguistic Research, 49, 31-40. https://doi.org/10.1007/ s10936-019-09669-4

Serkin, V.P. (2016a). Metodika lichnostnyh konstruktov Dzhona Kejli [The questionnaire of personal constructs by J. Kelly]. Psihosemantika - Psychosemantics (pp. 160162). Moscow: Izdatelstvo Jurajt [in Russian].

Serkin, V.P. (2016b). Standartnyj semanticheskij differencial [Standard semantic differential]. Psihosemantika - Psychosemantics (pp. 178-183). Moscow: Izdatelstvo Jurajt [in Russian]. 
Shkuratova, I.P. (2019). Metodyka vyznachennia motyviv bezposerednoho $i$ oposeredkovanoho mizhosobystisnoho spilkuvannia [The Questionnaire: Motives of Direct and Indirect Interpersonal Communication]. URL http://dspace.pnpu. edu.ua/bitstream [in Ukrainian].

Stephens, K.K., \& Rains, S.A. (2011). Information and communication technology sequences and message repetition in interpersonal interaction. Communication Research, 38(1), 101-122. https://doi.org/10.1177/0093650210362679

Systema osvity v Ukraini [The System of Education in Ukraine]. (2015). URL https:// www.eduget.com/news/sistema_osviti_v_ukraini-115

Walther, J.B. et al. (2011). The effect of feedback on identity shift in computer mediated communication. Media Psychology, 14, 11-26. https://doi.org/10.1080/ 15213269.2010 .547832

Wright, K.B., \& Webb, L.M. (2011). Computer-mediated Communication in Personal Relationships. New York: Peter Lang.

Zdorovyi sposib zhyttia: osnovy ta pryntsypy [Healthy lifestyle: Fundamentals and Principles]. (2016). URL https://cheline.com.ua/news/zdorovja/zdorovij-sposibzhittya-osnovi-ta-printsi-10602

\section{АНОТАЦІЯ}

Мета. Дослідити психологічні особливості розуміння студентами Інтернеттекстів та визначити предиктори такого розуміння.

Методи та методичний інструментарій. У дослідженні використано такі методи: цілісний аналіз тексту, проблемно-тематичний та порівняльний аналіз. 3 метою вивчення дослідницького матеріалу використано описовий метод, метод послідовного аналізу, метод синтаксичної трансформації. В експериментальному дослідженні застосовано такі методики: авторський опитувальник "Визначення цілей міжособистісного спілкування в Інтернетпросторі (Nabochuk, 2020); «Методика визначення мотивів безпосереднього й опосередкованого міжособистісного спілкування» (Shkuratova, 2019); "Mетодика діагностики міжособистісних стосунків» (Leary, 2018).

Результати. Побудовано семантичний простір, що характеризує розуміння досліджуваними Інтернет-текстів публіцистичного дискурсу. Респонденти оцінювали зміст творів за 30 біполярними шкалами, що об'єдналися після проведення фракторного аналізу в 7 блоків-фракторів, які характеризували "оцінку» того або іншого Інтернет-тексту. (1). "Оцінка» - вдалий невдалий; цікавий - нецікавий; сильний - слабкий; приємний - неприємний; предикативний - непредикативний. (2). "Напруженість» або "сила»: тяжкий - легкий; напружений - легковажний; винятковий - буденний; скований - вільний; активний - неактивний; агресивний - неагресивний; авторитарний - демократичний. (3). "Реалістичність» або "життєвість» природний - вигаданий; близький - далекий; реальний - нереальний. (4). "Емоційний тон» - песимістичний - оптимістичний; сумний - веселий; егоїстичний - неегоїстичний; підозрілий - прийнятний. (5). "Глибина» або «психологічність» - психологічний - непсихологічний; твір-роздум твір-дієвість; серйозний - розважливий; розумний - нерозумний; логічний - 
нелогічний; комфортний - некомфортний; діалогічний - монологічний; залежний - незалежний. (6). "Абстрактність» - абстрактний - конкретний; фантастичний - реальний. (7). "Багатоплановість» - багатоплановий одноплановий; складний - простий; стислий - розгорнутий.

Висновки. Визначено чотири основні психологічні особливості розуміння студентами Інтернет-текстів. Цими особливостями $\epsilon$ : (1) розуміння тексту Інтернету за його контекстуальністю, предикторами якої $\epsilon$ : реальність, багатоплановість, парадигмальність, описовість, глибина, суб'єктність та особистісна центрованість; (2) розуміння Інтернет-тексту за його психологічним контекстом, що включає такі предиктори, як: психологічне обгрунтування, компресивність, зацікавленість, розважальність, задоволеність, гармонійність, емоційність, експресивність (або виразність); (3) розуміння тексту Інтернету за його емоційним контекстом, предикторами якого постають: комфортність, стилістична виразність, зручність, експресивність, легкість, розмовні характеристики, публіцистичний стиль; (4) розуміння Інтернет-тексту за його багатогранною парадигмою, яка характеризується такими предикторами: парадигмальністю, космічністю, актуалізованістю, стимулювальним характером, діалогічністю, комфортністю, легковажністю.

Ключові слова: Інтернет-текст, розуміння, психологічні особливості розуміння, предиктори розуміння, контекстуальність, психологічний контекст, емоційний контекст, багатогранна парадигма.

\section{Максименко Сергей, Немеш Елена, Максименко Ксения \& Набочук Александр. Психологические особенности понимания студентами Интернет-текстов}

\section{АННОТАЦИЯ}

Цель. Выявить психологические особенности понимания студентами Интернет-текстов и определить предикторы такого понимания.

Методы и методический инструментарий. С челью проведения научного исследования были использованы следующие методы: целостный анализ текста, проблемно-тематический и сравнительный анализ. Были также использованы описательный метод, метод последовательного анализа, метод синтаксической трансформачии. В эмпирической части исследования использовались такие метдики: авторский опросник "Определение челей межличностного общения в Интернет пространстве» (Nabochuk, 2020); "Методика определения мотивов непосредственного и опосредованного межличностного общения" (Shkuratova, 2019); "Методика диагностики межличностных отношений» (Leary, 2018).

Результаты. Смоделировано семантическое пространство, которое характеризует понимание респондентами Интернет-текстов публицистического дискурса. Респонденты оценивали содержание произведений с учётом 30 биполярных шкал, объединившихся после проведения фракторного анализа в 7 блоков-факторов, которые характеризовали «оценку» того или иного Интернет-текста. (1). «Оценка»: удачный - неудачный; интересный - 
неинтересный; сильный - слабый; приятный - неприятный; предикативный непредикативный. (2). «Напряжённость» или «сила»: тяжёлый - легкий; напряжённый - легкомысленный; исключительный - обычный; ограниченный свободный; активный - неактивный; агрессивный - неагрессивный; авторитарный - демократический. (3). "Реалистичность» или «жизненность»: естественный - вымышленный; близкий - далёкий; реальный - нереальный. (4). «Эмоциональный тон»: пессимистический - оптимистический; печальный весёлый; эгоистичный - неэгоистичный; подозрительный - приемлемый. (5.) "Глубина» или «психологччность»: психологический - непсихологчческий; сочинение-рассуждение - сочинение-действие; серьезный - рассудительный; умный - глупый; логический - нелогичный; комфортный - некомфортный; диалогический - монологический; зависимый - независимый. (6). «Абстрактность»: абстрактный - конкретный; фантастический реальный. (7). «Многоплановость»: многоплановый - одноплановый; сложный простой; краткий - развёрнутый.

Выводы. Сформулированы психологические особенности понимания студентами Интернет-текстов. Этими особенностями являются: (1) понимание Интернеттекста с учётом его контекстуальности, предикторами которой являются: реальность, многоплановость, парадигмальность, описательность, глубина, субъектность и личностная центрированность; (2) понимание Интернеттекста с учётом его психологчческого контекста, который включает такие предикторы, как: психологчческое обоснование, компресивность, заинтересованность, развлекательность, удовлетворённость, гармоничность, эмоциональность, экспрессивность (или выразительность); (3) понимание Интернет-текста с учётом его эмоционального контекста, предикторами которого мы считаем: комфортность, стилистическая выразительность, удобство, экспрессивность, лёгкость, разговорные характеристики, публицистический стиль; (4) понимание Интернет-текста с обоснованием его многогранной парадигмы, которая характеризуется такими предикторами: парадигмальность, космичность, актуализированность, стимулирующий характер, диалогичность, комфортность, легкомыслие.

Ключевые слова: Интернет-текст, понимание, психологические особенности понимания, предикторы понимания, контекстуальность, психологический контекст, эмоциональный контекст, многогранная парадигма. 